Relations industrielles

Industrial Relations

\title{
La gestion des ressources humaines : du modèle traditionnel au modèle renouvelé, Gilles Guérin et Thierry Wils. Introduction : Michel Audet. Commentaires - Comments: Laurent Bélanger, Richard J. Long, Bernard Galambaud
}

Volume 49, numéro 1, 1994

URI : https://id.erudit.org/iderudit/050924ar

DOI : https://doi.org/10.7202/050924ar

Aller au sommaire du numéro

Éditeur(s)

Département des relations industrielles de l'Université Laval

ISSN

0034-379X (imprimé)

1703-8138 (numérique)

Découvrir la revue

Citer cet article

(1994). La gestion des ressources humaines : du modèle traditionnel au modèle renouvelé, Gilles Guérin et Thierry Wils. Introduction : Michel Audet.

Commentaires - Comments: Laurent Bélanger, Richard J. Long, Bernard Galambaud. Relations industrielles / Industrial Relations, 49(1), 168-187. https://doi.org/10.7202/050924ar

Tous droits réservés (C Département des relations industrielles de l'Université Laval, 1994
Ce document est protégé par la loi sur le droit d'auteur. L’utilisation des services d'Érudit (y compris la reproduction) est assujettie à sa politique d'utilisation que vous pouvez consulter en ligne.

https://apropos.erudit.org/fr/usagers/politique-dutilisation/ 


\section{Symposium}

\section{La gestion des ressources humaines: du modèle traditionnel au modèle renouvelé}

\section{Introduction par Michel Audet}

Gilles Guérin et Thierry Wils ont récemment publié un volume** d'une grande qualité décrivant l'évolution de la gestion des ressources humaines par le passage d'un modèle traditionnel à un modèle renouvelé, résultat d'une mutation profonde de l'environnement. Cet ouvrage mérite d'être souligné car, jusqu'à présent, la majorité des auteurs en gestion des ressources humaines ont traité cette thématique de façon plutôt traditionnelle, accordant beaucoup d'importance à la longue série d'activités, de soussystèmes ou de programmes de gestion des ressources humaines que toute organisation doit accomplir afin de rencontrer à la fois ses objectifs économiques et sociaux. Guérin et Wils ont eu cette audace d'aborder la GRH sous un autre angle, donnant aux universitaires, étudiants et praticiens un éclairage neuf sur la conceptualisation du phénomène. Un tel ouvrage ne peut être passé sous silence c'est pourquoi le comité de direction de la revue Relations industrielles a décidé d'en faire un "symposium ", en mettant à contribution trois auteurs et universitaires de haut niveau, reconnus pour leurs écrits ou leurs recherches dans le domaine. Nous avons donc fait appel à Laurent Bélanger, professeur au Département des relations industrielles de l'Université Laval et auteur de plusieurs ouvrages majeurs dans le domaine, à Richard Long, professeur au College of Commerce, University of Saskatchewan et chercheur de réputation internationale, ainsi qu'à Bernard Gallambaud, directeur scientifique de l'Institut Entreprise et Personnel et acteur important dans le développement des connaissances en GRH en France. Chacun d'eux présentera une évaluation du livre, insistant sur ses forces et ses faiblesses. Malgré des différences quant aux origines géographique, culturelle et professionnelle des trois recenseurs, tous sont cependant d'accord pour affirmer que ce livre marquera le champ des connaissances en GRH, tant par son traitement rigoureux que par l'originalité de son approche.

* Audet, M., professeur, Département des relations industrielles, Université Laval.

** La gestion des ressources humaines : du modèle traditionnel au modèle renouvelé par Gilles Guterin et Thierry WiLs, Montréal, Presses de l'Université de Montréal, 1992, 276 p., ISBN 2-7606-1561-8. 
Over the past 20 years, the field of human resource management (HRM) has been characterized by the publication of many classic books. Each of them has integrated the traditional operational activities of HRM in a systems approach. Gilles Guérin from Université de Montréal and Thierry Wils from Université du Québec à Hull recently published a book entitled La gestion des ressources humaines : du modèle traditionnel au modèle renouvelé. Adopting a rigourous and original approach, this book addresses the evolution of HRM and seeks to demonstrate the reasons why modern organizations and managers have recently adopted or should adopt in the future, a renewed model of HRM. For this reason, the executive committee of the Review decided to organize a review symposium with the support of three well known authors and researchers in the field of HRM. Those reviewers are Laurent Bélanger from the Industrial Relations Department at Universite Laval, Richard J. Long from the College of Commerce at the University of Saskatchewan and Bernard Gallambaud, scientific director at the Institut Entreprise et Personnel in France. Richard J. Long accepted to review the book in English; the other two reviews are in French. Despite their different approaches to the subject, all are in agreement that Guérin and Wils have made a significant contribution to the study of HRM.

\section{Commentaire par Laurent Bélanger}

Depuis sa parution, cet ouvrage a connu une notoriété remarquable tant chez les praticiens de la gestion des ressources humaines que chez ceux qui œuvrent dans les milieux académiques d'expression française. Il faut reconnaître, au départ, qu'il s'agit là d'une contribution nettement différente des ouvrages publiés à ce jour qui mettent en évidence aussi bien la perspective stratégique que la dimension opérationnelle de la gestion des ressources humaines : une appellation nouvelle pour identifier ce domaine spécialisé de la gestion des organisations, au lieu de l'expression " gestion du personnel " plus ancienne et revêtant au départ un caractère plutôt technique et procédurié. De fait, l'ouvrage ne vise pas à enseigner la bonne manière de gérer les ressources humaines d'une organisation, mais il se veut avant tout un relevé descriptif, analytique et critique des deux modèles de gestion des ressources humaines : l'un traditionnel, l'autre nouveau, tout en faisant état des changements importants dans l'environnement des organisations, changements qui incitent les spécialistes du domaine à s'interroger sur la nature et l'efficacité de leur contribution.

Pour en faciliter la lecture (ou la relecture), nous proposons ici une sorte de guide qui mettra en évidence la manière dont l'ouvrage a été rédigé et qui soulèvera certaines questions susceptibles d'inciter le lecteur à poursuivre sa réflexion.

L'ouvrage comprend trois chapitres : la présentation du modèle traditionnel, une description des changements majeurs d'ordre économique, technologique, socioculturel, politique et la présentation du modèle renouvelé. La rédaction des chapitres qui traitent des deux modèles obéit aux paramètres communs suivants :

* BÉlanger, L., professeur, Département des relations industrielles, Université Laval. 
- Les attitudes des gestionnaires, c'est-à-dire, les croyances et les opinions des gestionnaires quant à la place et à l'importance de l'élément humain dans les organisations. Les attitudes renvoient à une vision de la main-d'œuvre qui diffère au passage d'un modèle à l'autre.

- La fonction ressources humaines, c'est-à-dire la nomenclature des responsabilités et des activités normalement assumées par les chefs linéaires ou accomplies par les spécialistes du service des ressources humaines. Sans faire de distinction étanche entre la fonction ressources humaines au sens large et le service, les auteurs procèdent à un fractionnement de ce second paramètre en retenant les éléments suivants :

- les objectifs poursuivis par la fonction,

- la philosophie de gestion ou vision de la personne humaine au travail,

- le pouvoir inhérent à cette fonction, les caractéristiques mêmes de la fonction ou types de gestion,

- la description des activités de design du travail, de recrutement, de sélection, de formation, de rémunération, d'évaluation et de gestion des relations du travail.

- Les rôles et l'efficacité des services de ressources humaines forment le troisième paramètre. On s'intéresse ici plus particulièrement au fonctionnement des services de personnel au sens restrictif et administratif du terme " services".

- Le statut et les compétences des spécialistes de la gestion des ressources humaines constituent le dernier de ces quatre paramètres qui servent de piliers à la démonstration de l'émergence d'un modèle renouvelé susceptible de servir d'alternative au modèle traditionnel.

En gardant à l'esprit ces quatre grands paramètres, le lecteur peut procéder à une lecture de l'ouvrage en empruntant une démarche comparative plaçant le modèle traditionnel en regard du modèle renouvelé sur chacun des paramètres ou des éléments d'un paramètre.

En procédant ainsi par voie de comparaisons, il obtient une vision synoptique de ce qui caractérise chacun des modèles et de ce qui les différencie. De telles comparaisons permettent de retenir les éléments majeurs qui constituent l'argumentation des auteurs en faveur du modèle renouvelé.

Au plan des attitudes des gestionnaires, on constate que dans la vision traditionnelle, la main-d'œuvre est considérée comme interchangeable, abondante, comme un coût de production; alors que dans un modèle renouvelé, elle apparaît plutôt comme une ressource critique d'une importance plus grande que tout investissement dans l'équipement, la technologie, etc.

Dans le modèle traditionnel, la fonction " personnel " poursuit des objectifs multiples non intégrés à ceux qui prévalent pour l'ensemble de l'organisation, alors que dans le modèle renouvelé, les objectifs sont élaborés avec un souci d'opérationnalité, c'està-dire le souci de favoriser des indicateurs de mesure permettant une évaluation plus adéquate de la contribution de cette fonction à la performance économique et financière de l'entreprise.

La vision de la personne humaine qui s'infère des énoncés de la théorie « $X$ » de McGregor sert à maintenir, voire même, à consolider la distance sociale qu'on entend 
instaurer entre la direction des entreprises et les salariés en cantonnant ces derniers dans un rôle d'exécutant. Par contre, la philosophie de gestion qui renvoie aux énoncés de la théorie « $Y$ » du même auteur ouvre la voie à une participation possible des salariés aux décisions qui les concernent et sert de fondement au modèle renouvelé, qui veut faire de la gestion des ressources humaines la création de lieux de travail répondant un peu plus aux aspirations des diverses catégories de personnel impliquées dans un effort collectif de production.

Quant au pouvoir qu'on voudrait attribuer à cette fonction, les auteurs croient qu'il est plutôt faible, voire insignifiant, dans le modèle traditionnel à cause de l'absence de liens évidents entre le succès d'une organisation et la contribution de cette fonction. Dans un modèle renouvelé, le pouvoir serait visiblement exercé en mettant en évidence l'importance des ressources humaines dans l'élaboration et la mise en cuvre des stratégies de l'entreprise.

Avec la présentation et l'analyse des caractéristiques de la gestion qu'on retrouve dans l'un ou l'autre des modèles, on aborde un ensemble de comparaisons qui contribuent le plus à mettre en évidence les deux modèles : le traditionnel et le renouvelé. De fait, la gestion du personnel dans le modèle traditionnel prend un caractère bureaucratique misant sur l'application de règles définies unilatéralement ou de façon conjointe dans les secteurs syndiqués. Dans ce dernier secteur, la convention collective devient un outil tout indiqué de gestion en l'absence de politiques et de procédures précises. La gestion du personnel prend également un caractère techniciste axé sur le comment on fait les choses, sans être certain si l'on fait toujours les bonnes choses, puisqu'on est appelé à agir par à coup et après coup : ce qui confère à la gestion du personnel un caractère réactif. Dans un modèle renouvelé, la gestion des ressources humaines prend un caractère intégré, contingent, culturel et proactif : le caractère intégré origine d'un effort en vue d'établir une cohérence entre les objectifs de l'organisation et ceux de la fonction « ressources humaines", entre les stratégies retenues par les directions générales des entreprises et les stratégies d'utilisation et de mobilisation des ressources humaines. L'idée d'harmonisation des stratégies, tout en conférant à la gestion un caractère d'intégration ou de cohérence, imprime également à la gestion des ressources humaines un caractère de contingence : c'est-à-dire que les stratégies de ressources humaines doivent s'ajuster à la nature du contexte économique, politique et socio-culturel, externe à l'organisation.

En plus de s'inscrire dans le courant des théories de la contingence, la nouvelle gestion des ressources humaines se veut anthropogène, mobilisante, et partant, plus culturelle. En effet, elle incite à réviser l'organisation traditionnelle du travail et à créer des conditions susceptibles non seulement de répondre aux besoins humains, si bien décrits par Maslow, mais faire plus en tentant de " rapprocher les attentes sociales » et les impératifs économiques. Le partage de valeurs communes à un regroupement humain, un projet partagé, l'ouverture sur l'extérieur, l'ouverture des communications à l'interne sont autant d'ingrédients susceptibles de déborder le cadre restreint de la motivation au travail pour lui substituer le concept de mobilisation et d'implication. On sait bien qu'une telle mobilisation, à tort ou à raison, ne peut se réaliser sans qu'une direction d'entreprise cherche à diffuser ses propres valeurs qu'elle voudrait voir partagées non seulement par les cadres mais par tous les salariés. Suite à l'engouement à 
l'égard d'un nouveau management diffusé dans des « best sellers » connus, c'est en partie la manière dont les directions d'entreprise cherchent à imprimer un caractère culturel à la gestion des ressources humaines.

En plus de prendre un caractère contingent et culturel, la nouvelle gestion des ressources humaines se veut proactive et soucieuse de l'évaluation de son efficacité. Au lieu de se limiter à répondre à des demandes ponctuelles originant de tous les secteurs d'une organisation, la gestion renouvelée doit emprunter une démarche proactive aux plans stratégique et opérationnel en invitant les chefs linéaires à prendre en considération la dimension « ressources humaines " dans les choix qui sont critiques pour l'avenir d'une organisation.

La nouvelle gestion des ressources humaines se veut aussi préoccupée d'évaluation. L'évaluation constitue toujours le «talon d'Achille » de la gestion des ressources humaines et apparaît comme une faiblesse chronique. Pour corriger cette situation, il faudrait faire un effort d'opérationnalisation des objectifs de la fonction, d'élaboration d'indices appropriés de mesure d'efficacité, sachant bien que les véritables facteurs qui contribuent au succès d'une organisation ne se retrouvent pas uniquement dans le domaine des ressources humaines, bien au contraire. Cependant, en dépit de ces embûches, l'idée d'évaluation de l'efficacité de la GRH fait son chemin et on voit poindre de plus en plus des exemples de démarches appropriées.

La présentation succincte des activités normalement accomplies en gestion des ressources humaines dans les deux modèles devient le dernier élément du paramètre : «fonction des ressources humaines". Les activités inhérentes à la fonction dans sa dimension traditionnelle respectent le principe de la division du travail « une personne - un poste " où le critère d'ancienneté domine et l'opposition systématique demeure la caractéristique principale des relations du travail. Abordant succinctement les activités de relations du travail, le modèle renouvelé s'inscrit plutôt dans un mode de relations sociales de travail marqué par la collaboration. En ce faisant, il est susceptible de déboucher sous une forme de « contrat social » dont la perspective temporelle déborde largement la durée normale des contrats collectifs de travail.

Le troisième paramètre retenu par les auteurs pour effectuer leurs comparaisons se donne comme objet l'étude des anciens et des nouveaux rôles assumés par les services des ressources humaines au passage d'un modèle à l'autre. Sans simplifier indûment la réalité, il faut se rappeler que les services de personnel ont, au départ, été mis sur pied pour alléger la tâche des gestionnaires des services opérationnels en matière d'acquisition, de maintien en poste et de développement de la main-d'œuvre au service des entreprises. Seulement au chapitre du maintien en poste (conservation des ressources), la dimension relations du travail occupait plus de la moitié du temps des spécialistes du service des ressources humaines, du moins, dans les secteurs fortement syndiqués.

La réalité qui prévalait au moment de la mise sur pied des services a fait en sorte qu'ils ont été longtemps perçus comme des «fournisseurs de services », des agents de rationalisation du travail de production et du travail administratif et des gestionnaires de contrats. De plus, ces services étaient fournis à la demande, un peu à la pièce, de sorte qu'il existait un manque de cohérence ou d'intégration et une faible préoccupation pour la mesure de l'efficacité. Le nouveau modèle cherche bien entendu à corriger ces 
faiblesses en faisant du service un partenaire stratégique, c'est-à-dire un aide précieux au moment de l'élaboration et de la mise en œuvre des stratégies, d'où le rôle d'« architecte" ou d'agent de changement qui servent maintenant à qualifier la nouvelle contribution fournie par ces services avec en plus, une préoccupation d'imputabilité.

Dans la même foulée, le dernier paramètre devient une interrogation sur le statut des spécialistes et sur la nature des qualifications requises pour assumer leur nouveau rôle. Souvent perçu par les gestionnaires des services opérationnels comme un " gêneur ", un empêcheur de tourner en rond, le spécialiste des ressources humaines ne pouvait s'attendre à beaucoup de considération de la part de ses collègues de travail. Au plan des qualifications, il faut reconnaître que les spécialistes présentaient certaines lacunes au plan d'une formation académique poussée et au plan de la connaissance du fonctionnement économique et financier des entreprises. Cette situation se reflétait également dans une rémunération plus faible que ses collègues. Pour atténuer l'aspect plutôt négatif de ce tableau, il faut reconnaître que parmi ces spécialistes certains sont devenus d'habiles négociateurs et ont contribué à stabiliser les tensions et les conflits au sein du régime de relations du travail au cours de la période 1945-1975, que certains ont appelé les « trente glorieuses ». De nos jours, les spécialistes du personnel possèdent pour la plupart un diplôme universitaire, connaissent mieux les rouages des entreprises et ont acquis des connaissances et une expérience qui débordent largement le contexte juridique des relations du travail. Ce phénomène se reflète dans des perspectives et des cheminements de carrière relativement différents de ceux qu'on a connus dans le passé.

Les deux modèles - le traditionnel et le renouvelé -, entrecoupés par un chapitre sur les changements contextuels survenus au cours des deux dernières décennies, placés en regard l'un de l'autre le long des quatre paramètres qui ont servi à son échafaudage, nous situent d'emblée dans deux univers différents, marquant une rupture entre un passé lointain et un horizon nouveau, celui de l'an 2000. Les auteurs, en plus de reconnaître au départ la faiblesse des données empiriques qui auront servi de support au modèle renouvelé, seront probablement les premiers à admettre également qu'il n'existe pas de rupture temporelle aussi prononcée entre les deux modèles que les éléments contrastants minutieusement accumulés le laissent croire. En effet, avec un peu d'imagination, on pourrait concevoir un modèle mitoyen qui se situe à mi-chemin entre le traditionnel et le renouvelé qui permettrait de mieux englober la réalité des changements survenus dans la gestion des ressources humaines avec le passage du temps. Certaines organisations, œuvrant dans le secteur public, se présentent au premier abord comme des structures rigides, bureaucratiques ou technocratiques, pour révéler par la suite quelques expériences timides d'actualisation des concepts de gestion stratégique, de stratégies de gestion des ressources humaines, d'approche système et d'imputabilité.

Également, dans le secteur privé, on retrouve certains dinosaures où le modèle traditionnel de gestion des ressources humaines demeure dominant surtout dans les secteurs fortement syndiqués. Une telle situation n'empêche pas ces mêmes entreprises de créer des îlots de créativité, d'autonomie par leurs professionnels, voire même leurs salariés en mettant sur pied de nouvelles formes d'organisation du travail, plus particulièrement des groupes autogérés. C'est un peu le cas d'une entreprise aussi colossale que G.M. qui réussit à abriter dans son sein des expériences comme celle de "Saturn » ou celle de NUMMI (G.M. Toyota). À ce sujet, les auteurs passent sous silence l'évolution 
évidente des procédés de fabrication (passage d'une production artisanale à une production-au-plus-juste toyotisme) et leur impact sur le design des organisations (lean production) et sur l'organisation du travail comme telle.

La faiblesse du support empirique et la rupture trop brutale entre les deux modèles (cette dernière probablement voulue pour des raisons pédagogiques), ne sont pas les seuls éléments à soulever des interrogations dans l'esprit du lecteur. En s'appuyant sur une multitude d'ouvrages, la plupart originant des secteurs universitaires, les deux auteurs concluent rapidement à un constat d'échec en dénonçant le caractère techniciste, éclaté du modèle traditionnel, etc. alors qu'il faut bien admettre qu'il s'agit là encore du modèle dominant en ce moment. Alors, comment expliquer un tel phénomène ? Les spécialistes du domaine feraient-ils preuve de résistance au changement ? et quoi encore ? Le modèle traditionnel, en demeurant encore le modèle dominant surtout dans le secteur public, conserve, sans qu'on puisse le prouver de façon scientifique, une certaine utilité, voire même une certaine efficacité dans l'instauration et le maintien d'un ordre et d'une discipline au sein des organisations de travail. Il faut reconnaître qu'une multitude de personnes formées dans nos universités, plus particulièrement nos départements et nos écoles de relations industrielles, ont acquis avec le temps une remarquable maîtrise du domaine des relations du travail, un art de la négociation et de l'administration des conventions collectives. Elles ont ainsi consacré, au sein des directions de ressources humaines, une bonne proportion de leur temps à maintenir une paix industrielle relative, nécessaire à la stabilité des opérations de fabrication et de distribution des biens et des services. En consacrant une page ou deux à l'activité de gestion des relations du travail dans l'un et l'autre modèle, les auteurs ne rendent pas tout à fait justice à la contribution de ces hommes et de ces femmes à l'instauration et au maintien d'un climat de relations du travail relativement viable au sein des établissements.

Les auteurs auraient pu s'interroger plus longuement sur notre régime québécois de relations du travail et se demander dans quelle mesure un tel régime retarde l'avènement d'un modèle renouvelé de gestion des ressources humaines, plus particulièrement, au chapitre de l'encadrement qu'il confère au statut du salarié. Le modèle renouvelé de GRH s'adresse plutôt au salarié du « troisième type », c'est-à-dire une personne plus scolarisée, capable d'exercer une plus grande autonomie, de faire équipe avec d'autres et de cogérer aussi son travail, alors que le modèle traditionnel postule plutôt l'image tayloriste du travailleur salarié, c'est-à-dire celui d'un simple exécutant, plus précisément, le type de salarié qu'on distingue nettement du « donneur d'ouvrage », distinction qui sert encore de pierre angulaire à notre régime juridique des relations du travail. Les auteurs eux-mêmes reconnaissent que les pratiques de relations du travail sont plutôt d'essence mécaniste s'harmonisant avec l'approche bureaucratique en gestion. Par conséquent, si l'on conclut à l'échec possible du modèle traditionnel, il faudrait en chercher les raisons non seulement dans son caractère de juxtaposition d'activités différenciées mal abouchées les unes aux autres, mais également dans des facteurs qui sont externes au modèle et qui incitent une multitude de gens impliqués à s'en accommoder.

En conclusion, en dépit de ces quelques lacunes, nous continuons à maintenir notre appréciation de l'ouvrage comme étant une contribution originale et majeure dans le domaine de la gestion des ressources humaines. Elle permet de réunir d'une manière logique et critique la contribution de la multitude d'auteurs dont fait foi l'abondante bibliographie couvrant tous les aspects anciens, actuels et nouveaux du domaine. 


\section{Comment by Richard J. Long}

It was with some trepidation that I accepted the task of reviewing this book, given my limited command of the French language. However, my fears proved to be groundless, as this book is very well organized and highly readable, with many tables, graphs, and other devices to enhance its readability.

In essence, what the authors are attempting to do is to specify a model of the human resource function in organizations, one that can meet the demands of a changing organization in a changing society. To do this, they first present a model of how the management of human resources has traditionally been seen, and then analyse how conditions have changed so as to render that model obsolete. They then describe a 'new' model that they believe will suit these changed conditions. A final section anticipates and discusses some of the criticisms of this new model, and identifies its limitations.

The book does all this in four chapters. The first describes the modest and narrow role traditionally played by the human resource department, and explains why this has been so. To do this, the authors first look at the way in which the generic process of managing human resources has traditionally been viewed, and how this has shaped the nature and responsibilities of the human resources department and the profile of the typical human resources professional.

Essentially, they argue that the field of human resource management has had to endure a position of low status and low importance, in the eyes of line management in general, and top management in particular. This stems from the classical view of the nature of labour itself: that it is naturally abundant, that it is homogenous (and hence easily replaceable), that it is simply a cost to be minimized, and that workers are simply an adjustable cog in the organizational 'machine'. If the problem of labour is not seen as a complex or difficult one, the human resource function will not be seen as an important player in organizational affairs.

They go on to present other reasons for the sorry plight of the human resources (HR) function. An important one is that its purpose is ambiguous - is it to minimize the cost of labour, or is it to maximize the happiness of workers? This reflects the two 'traditional' schools of thought that might be adopted by traditional managers - identified as either the 'classical' or 'human relations' schools of thought by Miles (1965).

Finally, they look at the human resources professionals themselves. In many cases, those put in charge of the HR department have been those who are not seen as competent to do anything important. Often HR managers have no formal training, nor do they have much knowledge of the organization as a whole. Even when they do have training, it is often criticized as being 'too academic'. A job in personnel is often seen as a dead end in terms of future career development. All of this is reflected in the salaries of HR managers, which are the lowest of the key managers in the organization.

In short, the human resources department is often caught in a vicious circle. They are given few resources and little power, but are blamed when things go wrong. This

* LONG, R.J., Pofessor, College of Commerce, University of Saskatchewan. 
confirms their image as being of marginal competence, and justifies the withholding of resources and opportunities for influence from them. They are also a convenient scapegoat for the increasing inadequacies of traditional organizational structures - structures which HR practitioners have absolutely no power to change.

The second chapter describes various changes in the business environment that affect the management of human resources, in terms of the economy, technology, labour force, social values and the role of governments and labour unions. Key economic changes are reduced growth, increased uncertainty, and increased competition. Key technological issues include changing production technologies and new technologies, such as biotechnology. Labour force trends include aging, feminization, increased ethnic diversity, and higher levels of education. Changing values include the view that work should not be the central feature of life, less acceptance of authority, and more concern with demanding rights. Institutional trends include the increasing role and influence of governments and the declining role and influence of organized labour. All of these changes are thoroughly documented, and also applied specifically to the Québec environment. This is perhaps the best exposition of these changes that I have seen in either French or English.

Each of these changes has implications for the management of human resources. If companies need to be innovative and produce products of higher quality at lower prices, effective utilization of human resources will be the key to that. Changing technologies require the recruitment and training of employees who have specific skills but are also adaptable, as well as strategies to deal with those who have been displaced by technology. Labour force challenges include integrating women and ethnic minorities effectively into the organization, as well as accommodating highly educated and professional employees. Challenges arising from social values include providing a satisfying and participative workplace, and being able to adjust to a less compliant work force, which may refuse to work extra hours or to relocate at the convenience of the company. Government legislation creates many constraints that must be met, such as pay and employment equity. As union influence weakens, a major task for the HR function will be to develop an appropriate relationship with their unions.

If they can play a major role in meeting these challenges, HR departments will experience a concomitant increase in their power and stature, and perhaps even earn the respect of line management. If they fail to do so, this will be further evidence of their incompetence, and their position in the organization will be eroded further.

Chapter 3 presents the new model of the HR function. The authors start off by arguing that three attitudinal changes have occurred among line and top management: (a) that employees should be regarded as a valuable resource rather than simply a cost;

(b) that this resource is crucial in achieving organizational objectives; and (c) that managing this resource effectively is a complex and difficult matter.

The authors then sketch out how the management of human resources will change. First, there will be a shift from either productivity or satisfaction as the guiding goal, to a focus on aligning the human resources activities to further the overall goals or strategy of the organization, usually known as 'strategic human resource management'. Under this model, the power of the human resources department will increase, but 
specialists in the HR department will not be entrusted with full responsibility for human resource management; it will be a shared responsibility with line management.

The nature of human resources work will shift along five main dimensions. First, from disjointed to strategic, with all $\mathrm{HR}$ activities needing to be conducted in the light of the larger organizational strategy. Second, from bureaucratic forms of control to cultural, based on shared values, and from universal solutions to organizational problems to those that fit with the firm's environment. Third, moving from technology dictated job and organization design to employee empowerment and high involvement, as advocated by Lawler (1986). Fourth, moving from reactive to proactive - seeking to prevent problems by eliminating their underlying sources, rather than simply reacting to problems as they emerge. Fifth, moving to a framework in which evaluation of human resource programs and their contribution to the overall organization is ongoing and intensive.

In addition to their traditional responsibilities, there will be two main types of roles for the human resource department - as a 'strategic partner' and an 'operational partner'. The first will be in conjunction with top management, and the second in conjunction with operational or line management. Strategic roles will include scanning the organizational environment, participating in overall strategy formation, helping to evaluate the success of strategies as they pertain to human resources and organizational effectiveness, implementing strategic change, and monitoring the actual implementation of strategy. At the operational level, they will assist in identifying human resource problems, developing solutions to these problems, implementing these solutions, and educating line management in these matters. The key issue here is 'adding value' to organizational processes through better utilization of human resources.

There are numerous implications of these new roles for the human resources specialists. They will have the opportunity to enjoy increased stature and power within the organization, but to achieve this, they must be able to live up to the higher expectations for them. They will require knowledge in three main areas. First, knowledge of the company, its products, strategy, and the roles played by other departments in the operation of the company. Second, they must be highly knowledgeable in the external and internal human resources environments, and have knowledge of the human resources subfunctions. Finally, they must have three crucial skills - analytical/diagnostic ability, creativity, and communications skills.

The final chapter deals with three main questions. First, is the 'new model' presented by Guérin and Wils truly new? Second, who benefits from the implementation of the new model? And, third, where can this new model be found in practice?

Throughout the book, the authors frequently acknowledge that the foundations of the 'new' model are not new, dating from the 1950s work of authors such as McGregor or Maslow, who argued that the classical model of organization was no longer adequate to stimulate the best performance from employees. The idea that traditional organizational structures are no longer appropriate in many environments dates from the 1970 s. The idea of strategic human resource management is somewhat newer, having been overlaid on the human resource assumptions of McGregor and Maslow and the views of the contingency theorists during the last ten to fifteen years. What is new, Guérin and 
Wils argue, is the extent to which the inadequacies of the traditional model for management of human resources are becoming apparent.

The second question discusses the charge made by some that 'new model' of human resource management is nothing more than an attempt by employers to undermine labour unions and thus bring labour more tightly under their control. Clearly, the new model is based on the assumption that the goals of employees and the company can be brought into harmony, and that trade unions, if they continue to exist, will need to drop or at least moderate their traditional adversarial approach. Guérin and Wils acknowledge that, in North America, especially in the United States, movement towards the new model has also been accompanied by a weakening of the labour movement. However, they argue that one has not caused the other, that instead both phenomena have been caused by the same underlying factors. As the traditional approach to management becomes obsolete, so does the traditional adversarial relationship between labour and management.

The final issue is to find examples of the 'new model'. If it is indeed crucial that organizations abandon the traditional model in favour of the new model, we should be able to find many examples of the new model. Yet very few examples can be found. The authors present some data relating to the advance of various forms of participative management, but the fact remains that full blown examples of the new model are virtually impossible to find.

They propose four possible reasons for this. The first is simply that most managers have experienced only the old model, and they don't really understand or know how to implement the new model. The second is the costs of implementation, which are tangible and immediate, while the benefits are intangible and long term. This leads to the third barrier, which is the preoccupation of North American managers with short term financial results. Finally, resistance may come from human resources professionals themselves, who may be reluctant to give up their role as the defender of employee interests within the firm, and who may be unsure of their ability to successfully adopt their new role.

To these reasons, they add some others, highlighted by critics of the model. For example, is there not a contradiction between the need for flexibility in the organization and the desire to establish a strong organizational culture? The new model is based on a type of partnership between managers and employees, and employee commitment to the organization is crucial. But why should employees be loyal to the organization if it will lay off hundreds of them in order to adapt to the changing environment?

In my view, the authors have omitted one of the most important reasons why the role of human resource management has advanced so slowly: virtually no chief executives have come out of the human resources function. This is damaging for two reasons. Since it has never been considered a route to the top, most high powered managers have avoided the HR department, robbing it of potential talent. Second, those at the top of the organization have had no direct experience with human resource management, and may have little appreciation that human resources professionals may have useful solutions to organizational problems. Indeed, it may be that many CEOs view the human 
resource department as more of a source of problems than as a source of solutions. The less they hear from the HR department, the better that things must be going!

What are the strengths and weaknesses of this book? Overall, I believe that the book accomplishes very well what the authors set out to do. Although there is really not much in the book that is new in itself, what is new is bringing everything together in one place, in a well organized and highly readable manner. The authors display an impressive command of the existing literature in the field, and cite more than 600 different sources throughout the book. I personally found the greatest strength to be Chapter 2, where the contextual changes facing North American organizations and their implications for the management of human resources are very well documented. I found the fourth chapter to be the least well developed, and it appears to have been added as an afterthought in order to preempt some of the anticipated criticisms of the book. I don't think it does that very effectively, but this may be a reflection of the limited empirical evidence available.

I think that this book will be very useful to HR professionals in understanding where human resource management has been, and in articulating and justifying a vision of where the HR function should be going. However, it provides them with very little guidance on how to actually get there. The authors' assumption seems to be that the forces for the new model are so strong, that its emergence is simply inevitable.

However, I would question whether this new model will be adopted by all organizations. The adoption of the new model is contingent on the adoption by top management of a general management philosophy that Miles (1965) describes as 'human resources', in contrast to the 'classical' or 'human relations' philosophies, on which the traditional model of human resource management is built. Yet even the most ardent proponents of the new philosophy (e.g. Lawler 1986; Miles and Snow 1978) acknowledge that there are circumstances under which the classical or human relations philosophies may still be viable.

Thus, I believe that it would have been useful for the authors to attempt to identify those types of organizations where the new model is most likely to be applied in the near future. Indeed, a weakness of this book is that the authors have not included any examples of firms that have managed to adopt the new model, how they did it, and what the results have been. Admittedly, such examples may be hard to find, but they are needed to give some sense that the new model is not simply a set of academic prescriptions which cannot be applied in the real world of organizations. The authors do provide some indirect evidence, for example, by citing the fact that Canadian firms appear to be adopting more workplace innovations, but do not provide any direct evidence.

In contrast to the new model, which is intended to be prescriptive, the traditional model is intended to be descriptive. But it may paint an overly bleak picture. The authors appear to have brought every possible criticism and shortcoming of traditional human resource management together and then put them all into one model. In fact, in some organizations the traditional model may work quite well. It is also likely that there is a wide variance in the extent to which that model is descriptive of actual human resources practices in a given firm. The authors present no empirical evidence on this, but this is probably because little direct evidence exists. 
But these criticisms pale in the light of the merits of the book. Overall, the authors have achieved their purposes admirably, and I would expect that both practitioners and students of human resource management will find a reading of the book to be a very worthwhile experience.

\section{REFERENCES}

LAWLER, E.E. 1986. High Involvement Management. San Francisco: Jossey Bass.

MiLes, R. 1965. “'Human Relations or Human Resources?', Harvard Business Review, July-August, 148-153.

MrLes, R., and C. SNOw. 1978. Organizational Strategy, Structure, and Process. New York: McGraw-Hill.

\section{Commentaire par Bernard Galambaud}

Gilles Guérin et Thierry Wils sont optimistes, du moins plus que moi ${ }^{1}$. Certes, nos regards ne portent peut être pas tout à fait sur la même réalité. Guérin et Wils regardent vraisemblablement, pour l'essentiel, le continent nord-américain, ses pratiques d'entreprises et sa littérature dont ils nous offrent en fait une synthèse. Quant à moi, je scrute l'Europe et plus particulièrement la France. Ceci dit, je ne suis pas sûr que toute différence entre nous puisse être réduite à cette seule différence géographique. Nos deux auteurs savent d'ailleurs, et le reconnaissent volontiers, que leur optimisme n'est pas nécessairement partagé par tous leurs collègues nord-américains, regardant pourtant le même espace. Nos deux auteurs savent également, me semble-t-il, même s'ils ne le disent pas vraiment, que le modèle renouvelé de gestion des ressources humaines qu'ils nous présentent, est plus dans l'espérance dont cette littérature est porteuse, que dans la réalité actuelle de la gestion des femmes et des hommes que les entreprises ont pu rassembler.

Bien sûr, des évolutions de pratiques de gestion de la mobilité et des carrières notamment, peuvent être lues comme des signes de la mise en cuvre de ce modèle renouvelé. Mais en même temps, le développement de la précarité du lien salarial, le développement de pratiques d'emploi recherchant une seule optimisation à court terme des ressources humaines, l'abandon de nombreux travailleurs dans un état de non-gestion, France.

* Galambaud, B., directeur scientifique, Institut Entreprise et Personnel, Boulogne,

1 Le recours à la première personne veut seulement signifier que ces pages ne sont qu'une contribution à un débat largement ouvert, et ne sont en conséquence que l'état provisoire d'une réflexion. 
l'apparition de plus en plus fréquente de comportements managériaux dominateurs et désinvoltes vis-à-vis du personnel, nous incitent au contraire à penser que plus d'une entreprise s'installe, à bien des égards, dans une espèce de régression sociale. Si Guérin et Wils ont raison, si un modèle renouvelé de gestion des ressources humaines se met en place, manifestement, il ne se met en place ni dans toutes les entreprises, ni pour tous les salariés. Ce modèle renouvelé s'installe vraisemblablement, au moins en Europe, dans une mise en cuvre d'une gestion des femmes et des hommes à "plusieurs vitesses $»$.

En fait, l'optimisme de Gilles Guérin et de Thierry Wils est lié à une posture intellectuelle qui nous interroge sur le rôle de l'enseignant-chercheur en gestion, et plus particulièrement en gestion des ressources humaines. L'enseignant-chercheur se doit d'accomplir un travail d'analyse critique de pratiques observées, afin d'en révéler, entre autres, les significations, le sens... Il y a science parce qu'il y a du caché, du non accessible à la compréhension directe et spontanée. Il appartient alors au chercheur de dévoiler, de mettre à jour, d'offrir une compréhension. Ce travail de dévoilement, ce travail de recherche proprement dit, se réalise le plus souvent contre l'opinion des gestionnaires, contre leur savoir, contre leur vérité.

Mais pour certains enseignants-chercheurs, ce travail de dévoilement est insuffisant. Il leur faut de surcroît offrir aux praticiens, aux gestionnaires, des pistes d'évolution pour leurs pratiques : évolution qu'ils sont vraisemblablement prêts à nommer " progrès ». C'est pour cela que dans toute une part de la littérature de gestion des ressources humaines, cohabitent, souvent sans le dire, l'œuvre de l'analyste, du chercheur, et cet appel au " progrès ". Ce modèle renouvelé est ainsi plus un référentiel pour une démarche de progrès qu'un modèle descriptif rendant compte de l'état des pratiques sociales de gestion. Ce modèle renouvelé est d'abord, me semble-t-il, (même s'il n'est pas que cela) un référentiel pour praticiens désirant conduire l'évolution de la gestion des ressources humaines dans leur entreprise.

Mais cette volonté un peu militante d'ouvrir un nouveau chemin, d'offrir de nouvelles voies pour l'action du gestionnaire, ne risque-t-elle pas d'occulter, peu ou prou, la réalité de l'entreprise, la réalité de ses pratiques de gestion des ressources humaines? Le désir de progrès ne peut-il pas altérer l'exigence d'analyse, de dévoilement? À trop vouloir servir la cause à laquelle il est attaché, à trop vouloir « voir enfïn les choses avancer », l'enseignant-chercheur ne prend-il pas le risque de développer un discours plus enclin à convaincre qu'à expliquer, plus pressé à mobiliser qu'à révéler?

Lorsque nos deux auteurs écrivent «une entreprise qui n'utilise pas toutes les compétences, qui ne prend pas tous les moyens pour encourager les travailleurs à donner leur plein rendement est une entreprise handicapée sur le plan de la concurrence ", ils prennent le risque d'être accusés de naïveté militante. À travers seulement les quarante dernières années de littérature managériale, les phrases de ce type là n'ont pas manqué. Et pourtant la réalité résiste... les choses ne doivent pas être aussi simples? Bref, le " militant » avec son discours militant, ses formules séductrices ${ }^{2}$, simplificatrices, généralisantes (même quand le discours plaide pour la contingence) n'obère-t-il pas l'action

$2 \mathrm{E}=\mathrm{MC}^{2}$, formule citée par les auteurs est une bonne illustration de ce discours. 
du chercheur? Dans le modèle renouvelé, du «militant» ou du chercheur, qui l'emporte?

\section{DE L'ARCHAISME À LA MODERNITÉ}

Le choix de présenter un modèle renouvelé opposé à un modèle traditionnel peut être lu comme une nouvelle page de cet universalisme que Guérin et Wils dénoncent par ailleurs, d'un universalisme « temporalisé » en quelque sorte. Bien sûr, des causes expliquant le passage d'un modèle à l'autre sont avancées : causes économiques avec la limitation de la croissance, l'accroissement de la concurrence, l'augmentation de l'incertitude, l'exigence de productivité; causes techniques avec l'innovation technologique sous ses diverses formes; causes socio-culturelles avec une main-d'œuvre plus âgée, plus féminisée, plus instruite aussi. Mais toutes ces causes restent bien générales; elles dépeignent un contexte. Elles justifient le passage du modèle traditionnel au modèle renouvelé. D'ailleurs, l'articulation formelle du livre se présente bien ainsi. Aussi, l'on ne peut s'empêcher de penser que, pour nos deux auteurs, la variable explicative majeure est l'histoire, et son sens est le temps sur la route du progrès. L'état de la gestion des ressources humaines dans une entreprise pourrait être positionné sur un continuum allant de l'archaïsme à la modernité. Et le « bon manager ${ }^{3}$, homme de progrès, conduirait l'entreprise sur cette route. Les entreprises à la gestion traditionnelle seraient des entreprises en retard sur l'histoire, et les entreprises à la gestion renouvelée seraient de leur temps. Être de son temps ne signifie nullement être à la mode. La logique de la mode renvoie à un véritable culte d'un présent social fondé sur l'éphémère et la séduction, comme le dit G. Lipovetsky ${ }^{4}$. Ici, il ne s'agit nullement de cela. L'on ne peut confondre l'idée de progrès et la «frivolité managériale ».

Le discours qui accompagne cette vision du progrès en marche, valorise le changement et son pilotage. Le «bon manager », homme de progrès, est en même temps " homme de changement ». Le changement, c'est le contraire de l'immobilisme. Le changement, c'est le mouvement, c'est le dynamisme! L'aspect normatif de cette perspective de progrès et de changement est évident. Quel manager accepterait volontiers de porter les couleurs de l'archaïsme et de l'immobilisme plutôt que celles de la modernité et du changement?

L'opposition archaïsme/modernité a déjà beaucoup servi. Ainsi en France, la notion de gestion de l'emploi s'est-elle de la sorte imposée dans le discours managérial et dans les pratiques de gestion, même si dans ces dernières, le succès est pour le moins mitigés. Au début des années 80 , à la suite des grandes restructurations de l'appareil productif national (textile, sidérurgie, machines-outils, constructions automobiles, chantiers navals, etc.), de grandes entreprises procèdent à d'importantes suppressions

3 L'expression «manager " est ici privilégiée à l'expression "gestionnaire », car en France, l'expression « bon gestionnaire " peut prendre une dimension péjorative, signifiant personnalité étriquée, un peu bornée, peu compatible avec l'idée d' « homme de progrès ".

4 G. LIPOVETSKY, L'empire de l'éphémère, Paris, Éditions Gallimard, 1987.

5 Patrick Gilbert et Bernard Galambaud, « La gestion prévisionnelle des ressources humaines en question ». Document de l'Institut Entreprise \& Personnel, Paris, 1993. 
d'emplois. Ả cette occasion, l'opinion découvre que le management des entreprises considérées n'avait le plus souvent rien anticipé, rien imaginé, rien prévu. Brutalement, des ouvriers et employés se retrouvent avec un savoir-faire professionnel déclaré sans valeur. Leur usine est classée «non viable », le produit fabriqué étant non compétitif, etc. Les suppressions d'emploi, particulièrement coûteuses, tant sur le plan financier que sur le plan humain, créent un grand désarroi dans beaucoup de directions d'entreprises et plus particulièrement dans les directions de ressources humaines. Alors, se développe un discours du type «plus jamais ça ». Ce discours affirme que les entreprises avaient vécu jusqu'alors sur un modèle traditionnel de gestion du personnel; modèle qui ne permettait pas les anticipations nécessaires. Mais maintenant, sous la pression de la crise économique, les entreprises évoluent vers un nouveau modèle appelé gestion de l'emploi basé sur l'anticipation des évolutions quantitatives et qualitatives des métiers et des compétences. De nombreux cabinets de consultants se proclament spécialistes de cette nouvelle discipline. Dans des entreprises cohabitent, plutôt mal que bien, une fonction gestion de l'emploi avec une fonction gestion du personnel ayant explicitement en charge les aspects traditionnels de la fonction. Cette émergence d'une gestion de l'emploi sur un mode d'opposition à la gestion du personnel, désignée comme traditionnelle, a largement eu, jusqu'à ce jour, plus un effet symbolique que réel. Le parallélisme entre cette apparition d'une gestion de l'emploi par opposition à une gestion du personnel, et l'apparition d'un modèle renouvelé par opposition à un modèle traditionnel est évident. Dans les deux cas, l'on décrit d'abord une gestion des ressources humaines aux performances médiocres, que les changements économiques et techniques rendent insupportables; puis ensuite, un nouveau modèle, qui constitue une avancée dans l'ordre du progrès.

\section{UNE SOUS-ESTIMATION DE L'IMPORTANCE DE L'ORGANISATION}

Gilles Guérin et Thierry Wils accordent une toute première importance aux dimensions culturelles de la gestion des ressources humaines. « $\grave{A}$ la base du modèle traditionnel - écrivent-ils dès le début de l'ouvrage - , se trouve un certain nombre de croyances ou d'opinions ". Il est vrai que la gestion des femmes et des hommes, au sein d'une entreprise, prend sa source dans les «cartes mentales » de ses dirigeants, de ses gestionnaires. Comment par exemple imaginer un développement des pratiques de gestion prévisionnelle dans une entreprise dont les principaux responsables ne croient qu'en l'importance de l'instant? Comment, autre exemple, ne pas voir la relation entre l'ampleur de la politique de promotion interne conduite dans une entreprise et la conception qu'ont les dirigeants de l'élite? De même, nous savons bien que certaines représentations mentales de l'entreprise favorisent un développement des politiques de fidélisation et de mobilité fonctionnelle de la main-d'œuvre, alors que d'autres représentations favorisent le développement du travail précaire ${ }^{6}$. De même encore, nous savons bien que si les employés administratifs sont une population largement non gérée, c'est parce qu'elle revêt aux yeux des dirigeants, à tort ou à raison, deux caractéristiques : la première, ne

6 M. Albert, Capitalisme contre capitalisme, Paris, Éditions du Seuil, 1991. 
représenter aucun intérêt stratégique; la seconde, ne renfermer aucune potentialité de danger social ${ }^{7}$ !

Mais cette explication par la culture, toute pertinente qu'elle soit, n'est que partielle. Elle ne peut, à elle seule, expliquer par exemple l'absence de finalité qui frappe aussi fréquemment les pratiques de gestion des ressources humaines, absence soulignée avec raison par Guérin et Wils qui rappellent que cette question de sens n'est pas récente. Déjà en 1954, Drucker percevait la fonction personnel comme un «salmigondis d'activités ». Quarante années plus tard, Drucker pourrait largement dire la même chose. Aujourd'hui encore, peu de directeurs généraux sont capables de formuler ce qu'ils attendent de leur direction des ressources humaines, hormis bien sûr quelques banalités sur la nécessité de prendre en compte le facteur humain. Ce qui est tout de même un peu court pour asseoir une politique ${ }^{8}$ !

Quant aux directeurs des ressources humaines, ils ne sont pas nécessairement plus explicites que leurs directeurs généraux sur la finalité de leur fonction. Quelle est l'origine de cette panne de sens? Pourquoi cette fonction, que l'on dit de plus en plus importante, est-elle incapable de se faire reconnaître des finalités explicites par les dirigeants d'entreprises? Pourquoi cette fonction, malgré un accroissement réel du professionnalisme de ses membres, est-elle toujours en recherche de ses buts? Cette panne de sens, me semble-t-il, est largement liée à une espèce d'incapacité, pour la fonction, à pénétrer toute une part de la réalité de l'entreprise. Nombreuses sont les actions initiées et conduites par des directions des ressources humaines, qui se sont rapidement, soit transformées en rituel bureaucratique, soit tout simplement éteintes après s'être plaquées sur l'entreprise. Nous pensons notamment à toutes ces pratiques d'appréciation de performances qui demeurent, malgré toutes les modifications qu'elles peuvent périodiquement subir, un exercice sans enjeux, sans importance; à tous ces entretiens de carrière sans conséquence d'aucune sorte pour personne; à toutes ces analyses d'emploi qui n'ont d'autre utilité que d'emplir les bureaux des analystes les ayant réalisées; à toutes ces cartes de métiers qui ne semblent assurer qu'une fonction esthétique, décorant les murs des directions des ressources humaines...

Cette incapacité à pénétrer réellement l'entreprise est vraisemblablement la conséquence d'une prise en compte bien insuffisante de la réalité organisationnelle par la fonction ressources humaines. C'est d'ailleurs là le reproche principal que je formulerai à l'encontre de l'ouvrage de Guérin et Wils; ils sous-estiment, de mon point de vue, cette réalité, comme la sous-estime d'ailleurs la plupart des auteurs. Bien sûr, le mot organisation revient fréquemment sous la plume de Gilles Guérin et Thierry Wils. Mais ce mot est trompeur car il est à signification variable. Il désigne tout aussi bien l'entreprise dans son ensemble, avec ses buts, ses moyens, ses membres, que le concept rendant compte de son seul système de production de biens ou de services. Dans cette signification restreinte, l'organisation assure une triple fonction : la relation entre le marché

7 Bernard GalamBaud, «Les employés administratifs : une gestion sans ambition ». Document de l'Institut Entreprise \& Personnel, Paris, 1993.

8 Bernard Galambaud, « Les pratiques de gestion des ressources humaines dans l'entreprise : à l'articulation entre l'organisationnel et le culturel ». Communication au séminaire de l'Institut des Sciences du Travail, Université Catholique de Louvain-La-Neuve, 1992. 
et le produit, le fonctionnement même du système de production (structures, système de coordination, gestion des flux de matières ou d'information), la réalisation de l'acte de production proprement dit. Or, cette dimension organisationnelle de l'entreprise (au sens du système de production) a une importance majeure pour la gestion des ressources humaines. Lorsque l'on dit que cette gestion est au service de l'efficacité de l'entreprise, c'est largement au service de ce système de production qu'elle est. La relation produit/ marché explique aussi, autre exemple, que dans plus d'une entreprise, l'on cherche tout à la fois à fidéliser quelques compétences jugées précieuses et à se donner la capacité d'opérer rapidement des ajustements de volume de main-d'œuvre. L'entreprise est alors composée d'un « centre » rassemblant la direction et toutes les compétences rares et de " périphériques " plus au moins éloignés, rassemblant par intérêt stratégique décroissant les autres salariés. Aussi, cette relation explique-t-elle le développement de la gestion des ressources humaines à " plusieurs vitesses ". Quant à l'articulation entre le fonctionnement de l'entreprise et l'acte de production proprement dit, elle a des conséquences directes tant sur la qualification des salariés, sur le contenu des emplois que sur le mode de management. Dans certaines entreprises, le fonctionnement du système de production est séparé de l'acte de production. L'ouvrier " producteur » est exclu de ce fonctionnement $^{9}$. Dans un tel cas, il est peu vraisemblable que se développe un management participatif. Pour participer à quoi, à quelles décisions? Dans d'autres entreprises, au contraire, l'ouvrier est à la fois « producteur » et membre de ce système de fonctionnement. Dans ce cas-là, il peut, il doit même, participer. Par exemple, le « juste-à-temps » le fait gestionnaire de flux; rôle qu'il doit assurer tout en maintenant sa fonction de « producteur » direct.

Aussi, tout discours général sur le développement du management participatif, ou sur la fin du taylorisme, est immédiatement contredit par une part de la réalité des entreprises.

Bien entendu, dans une entreprise, la réalité organisationnelle n'est pas indépendante de la réalité culturelle. Toute organisation concrète s'inscrit dans un système de valeurs a bien souligné Philippe Bernoux ${ }^{10}$. La gestion des ressources humaines prend bien sa source dans les convictions, croyances, représentations mentales, des gestionnaires. Mais, sous-estimer le système de production, c'est sous-estimer la partie la plus concrète de l'entreprise, celle où la situation de travail prend tout son sens.

\section{POUR UNE REMISE EN CAUSE DE LA LOGIQUE DES TERRITOIRES}

Cette incapacité de pénétrer la réalité organisationnelle de l'entreprise est liée à une espèce de tradition juridico-administrative de la gestion des ressources humaines. Combien de gestionnaires de ressources humaines ne gèrent en fait que des cœefficients de conventions collectives, des courbes de rémunération, des anciennetés dans l'emploi, dans l'entreprise, des descriptions de postes, des grades, des statuts, des titres, etc. Bref, combien de gestionnaires de ressources humaines ne gèrent en fait que des éléments

9 D. LINHART, «Quels changements dans l'entreprise? ", GIP Mutations Industrielles $n^{\circ} 39$, mars 1990.

10 Philippe Bernoux, La sociologie des organisations, Paris, Éditions du Seuil, 1985. 
appartenant à l'entreprise « formelle » et non à l'entreprise « réelle ». Ils gèrent le contrat de travail.

Cette tradition juridico-administrative de la fonction ressources humaines est elle même la conséquence d'une conception mécaniste de l'entreprise. Cette dernière est imaginée comme une juxtaposition d'entités : un bureau d'études qui conçoit, un atelier qui fabrique, des commerciaux qui vendent, des comptables qui tiennent les comptes, ...un gestionnaire des ressources humaines qui règlent les problèmes sociaux. Cette conception mécaniste développe une logique de territoire. Et qui dit territoire, dit frontières, batailles aux frontières, et/ou enfermement sur son territoire. L'on connaît bien les effets pervers de cette logique. L'atelier ignore le client, mais comment pourrait-il en être autrement? Les commerciaux ignorent les difficultés techniques, mais ce n'est pas leur affaire! Et l'atelier et les commerciaux se souviennent de l'existence de la fonction ressources humaines quand ils ont besoin de ses services... Cette conception mécaniste conduit chaque domaine à être traité de façon autonome. Et le traitement autonome du social conduit à sa marginalisation...

Pour mettre en œuvre le modèle renouvelé, la fonction ressources humaines sera contrainte de sortir de son « périmètre » habituel qui l'enferme dans le « formel », sera contrainte de prendre pied dans la sphère organisationnelle de l'entreprise. Et ceci bien sûr sans renoncer à son action culturelle, à son action sur les croyances, les convictions; sans renoncer en plus à ses activités juridico-administratives, ces dernières devant être assurées. Faut-il alors que la fonction ressources humaines élargisse son territoire, qu'elle obtienne un déplacement de ses frontières". Accroître le territoire n'est pas changer de logique, au contraire. Changer de logique, c'est travailler autrement. Changer de logique, c'est refuser la conception mécaniste de l'entreprise, c'est refuser le traitement autonome des problèmes, c'est accepter l'idée que les fonctions ont des missions et non des territoires, et que pour remplir ces missions de la meilleure façon possible, ces fonctions sont appelées, les unes et les autres, à parcourir le même territoire : celui de l'entreprise dans son ensemble. C'est accepter l'idée que les fonctions doivent réellement collaborer. Une direction des ressources humaines qui veut, par exemple, participer au choix de l'entreprise en matière de compétitivité, se doit, entre autres choses, de collaborer avec le contrôle de gestion afin de choisir la meilleure instrumentation possible. Une direction des ressources humaines qui, autre exemple, veut développer la compétence des salariés, veut asseoir leur qualification non plus sur le poste occupé mais sur la compétence apportée, ne peut se désintéresser de la division des tâches, de l'état du système de production. Bien entendu, ce raisonnement vaut aussi pour les autres fonctions.

Ce modèle renouvelé pose une fois encore la place de la fonction ressources humaines dans les processus de décision. Il est évident que la marginalisation de la fonction, son cantonnement dans l'entreprise formelle, ne lui a jamais valu une place de choix dans ces processus, hormis dans les bureaucraties. Dans ces dernières, les aspects réglementaires, statutaires, légaux ayant toujours une importance première, la fonction peut agir fermement " au nom de la loi » dans son propre domaine. Dans ces

11 Bernard Galambaud, «Quelles pistes d'évolution pour la gestion des ressources humaines? », Les Cahiers Français, 1993. 
bureaucraties, la direction des ressources humaines est d'abord une direction de la réglementation sociale; réglementation dont une bonne part est l'objet d'une négociation quasiment permanente avec les syndicats. Mais dans les autres entreprises, la fonction ressources humaines n'a souvent pour tout moyen d'action que sa propre capacité d'influence auprès des divers acteurs majeurs de l'entreprise. Or, une telle capacité est nécessairement fluctuante, variant selon les états des relations interpersonnelles, selon les circonstances du moment, selon les questions à résoudre... bref, dans un tel schéma la fonction est rarement en mesure de jouer un rôle central au sein de l'entreprise. Alors, pour échapper à toute culpabilisation, elle théorise son impuissance. C'est bien ce rôle que joue ce vieux discours du staff and line affirmant que la fonction personnel est une fonction de conseil qui ne doit surtout pas se substituer à la hiérarchie, mais seulement éclairer cette dernière.

Au terme de cette réflexion, je me demande tout de même si une part de mes critiques n'est pas inhérente à la méthode choisie par Gilles Guérin et Thierry Wils. Dans une livraison récente de la revue Sociologie du Travail, Denis Ségrestin fait remarquer combien le raisonnement par construction de modèles voit d'abord des discontinuités (le passage d'un modèle à l'autre), des ruptures, des changements de logique ${ }^{12}$. Par contre, le raisonnement à partir des pratiques voit nécessairement les compromis entre acteurs, les incohérences de l'action, les jeux stratégiques, les simulacres, les déformations des actions « officielles "... Bien sûr, le modèle nous offre la clarté de sa cohérence. Là est sa force, sa capacité attractive. Bien sûr, le modèle n'est pas la réalité. Mais qui $s^{\prime} y$ trompe? Si un tel modèle permet à des gestionnaires de mieux définir leur action et de mieux l'orienter, qui s'en plaindra? Si un tel modèle permet à des gestionnaires de mieux contribuer, grâce à une meilleure gestion des ressources humaines, à l'efficacité de leur entreprise, qui s'en plaindra? J'ai taxé, de prime abord, nos deux auteurs d'optimisme. Mais si cet optimisme, contenu dans leur modèle, se révèle une solide vertu pour l'action des gestionnaires de demain, qui s'en plaindra?

12 Denis SÉgrestin, «A propos du nouveau modèle productif », Sociologie du Travail, $n^{\circ} 1 / 93$ 